\title{
PERCEPATAN PERKEMBANGAN ANAK BUNGSU YANG ORANG TUANYA BEKERJA: Studi Perkembangan Anak Melalui Gambar dan Lukisan
}

\author{
Yofita Sandra \\ Fakultas Bahasa dan Seni, Universitas Negeri Padang \\ Email: yofita.sandra@fbs.unp.ac.id
}

\begin{abstract}
ABSTRAK
Kajian terkait perkembangan anak bungsu ini berupaya menjawab pertanyaan banyak orang yang mempertentangkan pendapat bahwa anak bungsu biasanya manja dengan anak bungsu yang dewasa terlalu dini. Anak bungsu yang dianggap manja karena semuanya difasilitasi orang tua secara totalitas sebagai bentuk kasih sayang berlebihan dan terlalu melindungi, sementara anak bungsu yang mandiri terlalu dini karena diasuh sama seperti anak-anak yang lebih tua darinya dan diperlakukan sama sehingga pola tindak-tindaknya menyerupai kakak-kakaknya yang jelas lebih tua. Anak-anak yang lebih cepat mandiri perbuatan dan pemikirannya ini diamati dari pola asuh yang kedua orang tuanya bekerja. Di saat orang tua bekerja, anak ditinggal bersama neneknya atau dengan pengaruh dan bahkan ada yang menitipkan pada tetangga yang juga punya anak dengan usia sebaya.

Observasi anak ketiga dari orang tua yang bekerja ini diamati selama 2 tahun menggunakan instrumen gambar atau sket pada kertas. 3 anak yang terdiri dari kakak adik kandung difasilitasi dengan kertas dan pensil untuk menggambar dan diminta melukiskan apa saja yang mereka ingin gambar. Namun demikian pada dasarnya pengamatan juga meliputi catatan perkembangan sikap, bahasa, dan sosial. Sebagai tambahan, penelitian juga menambahkan bentuk kemajuan yang dicapai oleh anak ke-3 dari 3 bersaudara yang jarak usianya berbeda masingmasing dua tahun.

Hasil temuan dari pengamatan ini membuktikan bahwa tidak saja orang tua kandung akan tapi juga orang-orang di lingkungan pengasuhan anak yang memberi pengaruh terhadap perkembangan fisik serta mental anak. Dan perkembangan anak ke-3 dari 3 bersaudara ini lebih cepat dibandingkan dengan perkembangan yang diraih oleh kakak-kakaknya pada usia yang sama. Percepatan kemajuan ini merupakan akses bagi diri anak sendiri untuk mandiri lebih awal.
\end{abstract}

Kata Kunci: anak bungsu, orang tua bekerja, kemandirian 


\section{PENDAHULUAN}

Harapan mengasuh anak sendiri oleh orang tua terkadang tidak semuanya dapat terpenuhi karena tuntutan karir. Demikian dengan pola pengasuhan anak yang barangkali hanya separuhnya yang dilakukan langsung oleh orang tua. Selebihnya diserahkan pada nenek atau pada jasa pengasuh anak sehingga hal ini juga membawa dampak positif dan negatif pada perkembangan fisik dan mental anak.

Idealnya anak pertama yang dalam keluarga mampu memberi contoh kepada anak kedua, ketiga, apa-apa yang menjadi aturan dalam keluarga. Namun hal tersebut belum berlaku untuk anak di bawah usia 10 tahun. Tingkah laku dan karakter anak kadang saling bertukar peran dengan anak yang lebih muda usianya karena adanya kompetisi dalam perebutan perhatian dan kasih sayang orang tua termasuk makanan dan mainan.

Bila dalam satu keluarga ada lebih dari dua anak, seperti tiga anak misalnya. Maka anak ketiga biasanya cendrung menjadi anak yang dominan menarik perhatian orang tua dalam hal perhatian, kasih sayang dan pemenuhan kebutuhan lain dan biasanya cenderung menjadi anak yang manja. Kenyataan di lapangan, anak ketiga atau anak bungsu ternyata tampil menjadi yang dominan dan memiliki karakter menuju superior.

Perkembangan anak usia 2 tahun sebagaimana yang disosialisasikan oleh American Academy of Pediatrics (2005) secara standar, contohnya: mampu menendang bola besar, mengingat foto-foto yang sering muncul, buku-buku yang sering dibacakan, bermain simulasi seolah-olah sendok itu pesawat terbang, merangkai 2 kata hingga 3 kata lebih, menyatakan hak milik, melompat di tempat. Sementara perkembangan anak usia 3 tahun itu menurut standar tersebut adalah mampu makan sendiri, berkata-kata hingga lebih dari 3 kata, merespon perasaan orang lain, melengkapi 3 hingga 4 potongan puzle. Dan pada kenyataannya sekarang anak usia 2 tahun telah mampu mengucapkan rangkaiatan kata-kata yang lebih dari 3 hingga 4 kata. Dan anak 2 tahun juga telah mampu memasang baju sendiri, makan suap sendiri dan memaksa untuk cuci tangan atau mandi sendiri. 
Hal ini diduga sebagai bagian dari pengaruh ditinggal orang tua bekerja. Dan hal inilah yang hendak dibuktikan lebih lanjut.

Beberapa acuan telah dilakukan pendidik dan peneliti untuk memantau perkembangan anak, baik pada kemampuan kognitif, afektif, dan psikomotor. Tidak hanya yang meliputi juga perkembangan bahasa, sosial, kultural akan tetapi juga penerapan nilai-nilai religi. Bila dalam satu fase, perkembangan ini dapat diamati melalui tingkah laku dan kemampuan sosialisasi. Pada kesempatan lain, perkembangan anak juga dapat dilihat dari coretan atau gambar anak.

Hughes (2005) menemukan bahwa objek-objek yang dipilih anak untuk digambarkan kembali menurut asumsi mereka cenderung terkategori pada empat hal, yaitu: hewan, tumbuhan dan sayuran, benda-benda terapan, dan kendaraan, yang berbeda dari tampilan animasi, kesamaan tampilan visual dan hal-hal yang telah dimanipulasi. Dan makhluk hidup cenderung lebih dipilih sebagaimana anak-anak meresponnya terkait dengan objek-objek lain.

\section{METODE}

Penelitian ini berbentuk studi kasus dengan pendekatan kualitatif yang sifatnya mengembangkan konsep, hipotesis, dan teori berdasarkan data dan informasi lapangan. Data yang dianalisis bersumber dari kumpulan gambar harian yang dihasilkan oleh anak-anak yang kebetulan anak penulis sendiri. Koleksi gambar yang dianalisa ditinjau pada rentang 2013 hingga 2017, dibantu oleh ibu penulis yang dahulu sebelum pensiun berprofesi sebagai guru seni rupa dan guru pada mata pelajaran apresiasi seni di tingkat sekolah kejuruan atau setingkat sekolah lanjutan atas.

Teknik pengumpulan data, pertama melalui observasi yang mengkover upaya pengambaran secara visual perkembangan anak pertama, anak kedua, dan anak ketiga. Kedua, melalui wawancara dengan orang-orang yang terlibat dalam keseharian anak serta orang tua atau nenek yang mendampingi anak-anak setiap hari dilengkapi dokumen serta referensi kepustakaan yang relevan. Analisis data dilakukan dengan model interaktif Miles dan Huberman (1992) melalui reduksi data, sajian data dan penarikan kesimpulan. 


\section{HASIL DAN PEMBAHASAN}

\section{Hasil}

Kumpulan gambar yang dihasilkan oleh anak pertama, anak kedua, dan anak ketiga dianalisis atas dasar pertimbangan tertentu. Pertama, saat anak mulai bersentuhan dengan pensil dan kertas untuk menghasilkan gambar, kedua, saat anak mulai menggambarkan objek-objek yang mereka senangi atau mereka idolakan, dan yang ketiga, saat anak menggambarkan peristiwa-peristiwa berkesan dalam kesehariannya..

Walau dengan corat coret sederhana, anak berusia 2 tahun sudah mampu mengarang cerita tentang gambar yang dihasilkan terkait dengan apa yang menjadi pusat perhatian mereka pada kesempatan tertentu. Kemudian menjelang usia 4 tahun, anak mampu memanfaatkan benda-benda di sekitar mereka untuk menambah variasi berkarya termasuk anggota tubuh mereka sendiri. Menggambarkan hewan-hewan berkarakteristik tertentu juga juga sudah mudah dihasilkan oleh anak 4 tahun menjelang usia 5 tahun, termasuk pada kemampuan menggambarkan figur orang-orang terdekat anak meskipun belum dengan proporsi sempurna.

Gambaran kemampuan anak dalam bakat dan minat serta orientasi respon positif pada lingkungan juga diketahui dari corentan anak. Karena anak pertama, berjenis kelamin perempuan, makan hal ini dianggap biasa dan wajar. Persepsi tentang gender belum dominan dalam karya yang dihasilkan. Hal-hal yang digambarkan oleh orang dewasa juga sudah mulai dicoba digambarkan oleh anak usia 3 hingga 4 tahun. Dalam struktur perkembangan anak pertama dianggap standar, atau hampir sama dengan perkembangan anak-anak lain yang sebaya usianya. Dengan perkataan lain belum terdapat keistimewaan tertentu selain dari intensitas berkarya yang terus menerus terjadi secara berkelanjutan.

Berikut ini gambar yang dihasilkan oleh anak pertama, saat mulai menyenangi kegiatan mencoret-coret kertas dan bercerita apa yang dipikirkannya. 


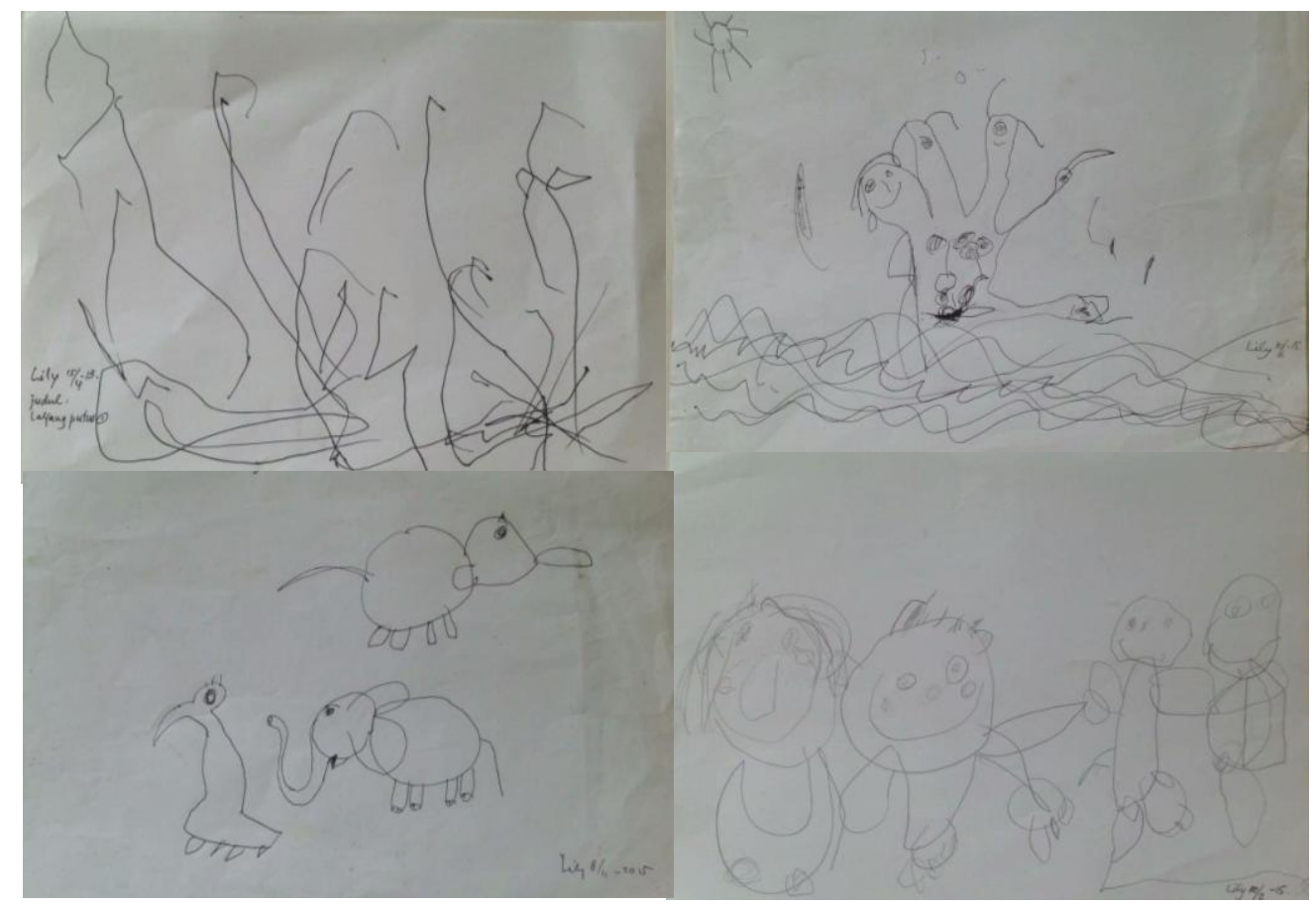

Keterangan:

a) Gambar anak pertama saat berusia 2 tahun

b) Gambar anak pertama saat mulai berkreasi dengan mencetakkan siluet tangan di kertas.

c) Gambar anak pertama saat mulai mengamati lingkungan fauna di sekitarnya atau yang dilihat dari televisi atau majalah

d) Gambar anak pertama saat mulai merespon orang-orang yang berada di sekelilingnya.

Ketika anak memasuki usia 3 tahun, perkembangan psikomotornya telah mulai beralih dari gerakan motorik kasar kepada gerakan motorik halus. Objekobjek yang digambarkan tidak saja yang berasal dari inspirasi sendiri tapi juga bersumber dari apa yang dilihat orang lain menggambarkan sesuatu. Benda hidup dan benda mati yang ada di sekitar anak menjadi ide utama berkarya. Kemudian coretan diperkaya dengan alfabet tertentu yang diyakini sebagai kata-kata penanda atau pengenal terhadap objek yang digambar.

Perkembangan anak pertama ini selanjutnya juga dapat dilihat dari gambargambar yang mereka coba hasilkan di kertas dengan pensil, pena, atau spidol berwarna. 


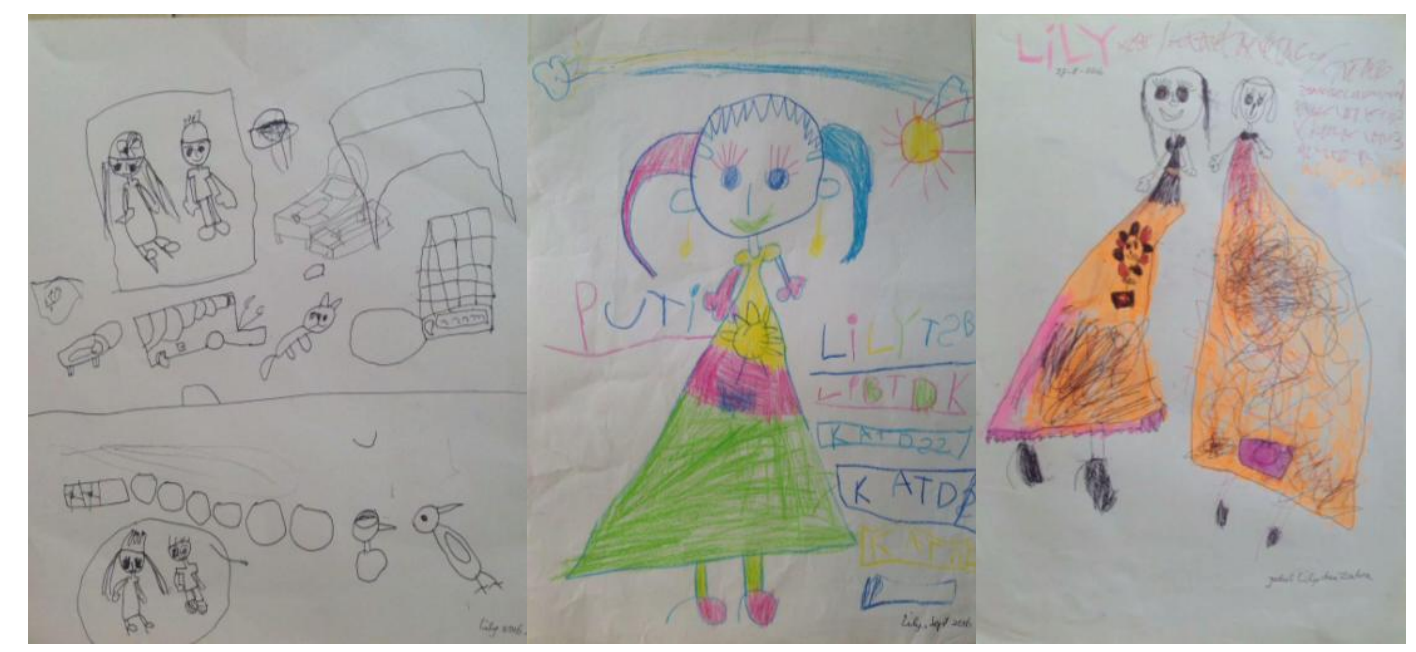

Keterangan:

a) Gambar anak pertama saat memasuk usia 5 tahun dalam menanggapi objekobjek yang ada di aktivitas kesehariannya di rumah.

b) Menggambarkan dirinya sendiri, dan

c) Menggambarkan dirinya bersama orang-orang yang sering mendampinginya ketika bermain.

Temuan terkait informasi yang diperoleh dari analisis gambar anak pertama yang perempuan akan berbeda halnya dengan temuan terkait informasi anak kedua yang berjenis kelamin lak-laki. Meski diasumsikan karya anak kedua merupakan hasil pengaruh dari karya anak pertama, pada usia yang sama yakni usia 2 tahun, saat mulai terlibat aktif menggambar, anak kedua tidak terlalu menitik beratkan pada cerita objek yang digambarkan. Melihat anak pertama menggambar, menggiring aktivitasnya untuk ikut menggambar.

Namun pada saat mendekati usia 3 tahun, anak kedua yang berjenis kelamin laki-laki telah menampakkan orientasinya yang lebih maskulin. Objek-objek raksasan dan perkasa seperti hewan buas atau dinosaurus menjadi perhatian pelik bagi anak kedua dan dicoba gambarkan di kertas. Terkadang anak memaksa orang tua untuk menggambarkan apa yang mereka inginkan karena menyadari belum seterampil anak pertama menggambar baru kemudian mereka berani mencoba sendiri menggambar objek yang mereka senangi tersebut. Kemampuan menata dan menyusun objek yang disenangi muncul dengan sendirinya setelah lama mengamati anak pertama berkarya. 
Munculnya kesadaran akan konsep perbedaan laki-laki dan perempuan pada anak kedua semakin dominan pada saat lahirnya anak ketiga berjenis kelamin perempuan. Berikut gambar-gambar yang dihasilkan oleh anak kedua berjenis kelamin laki-laki adalah sebagai berikut;

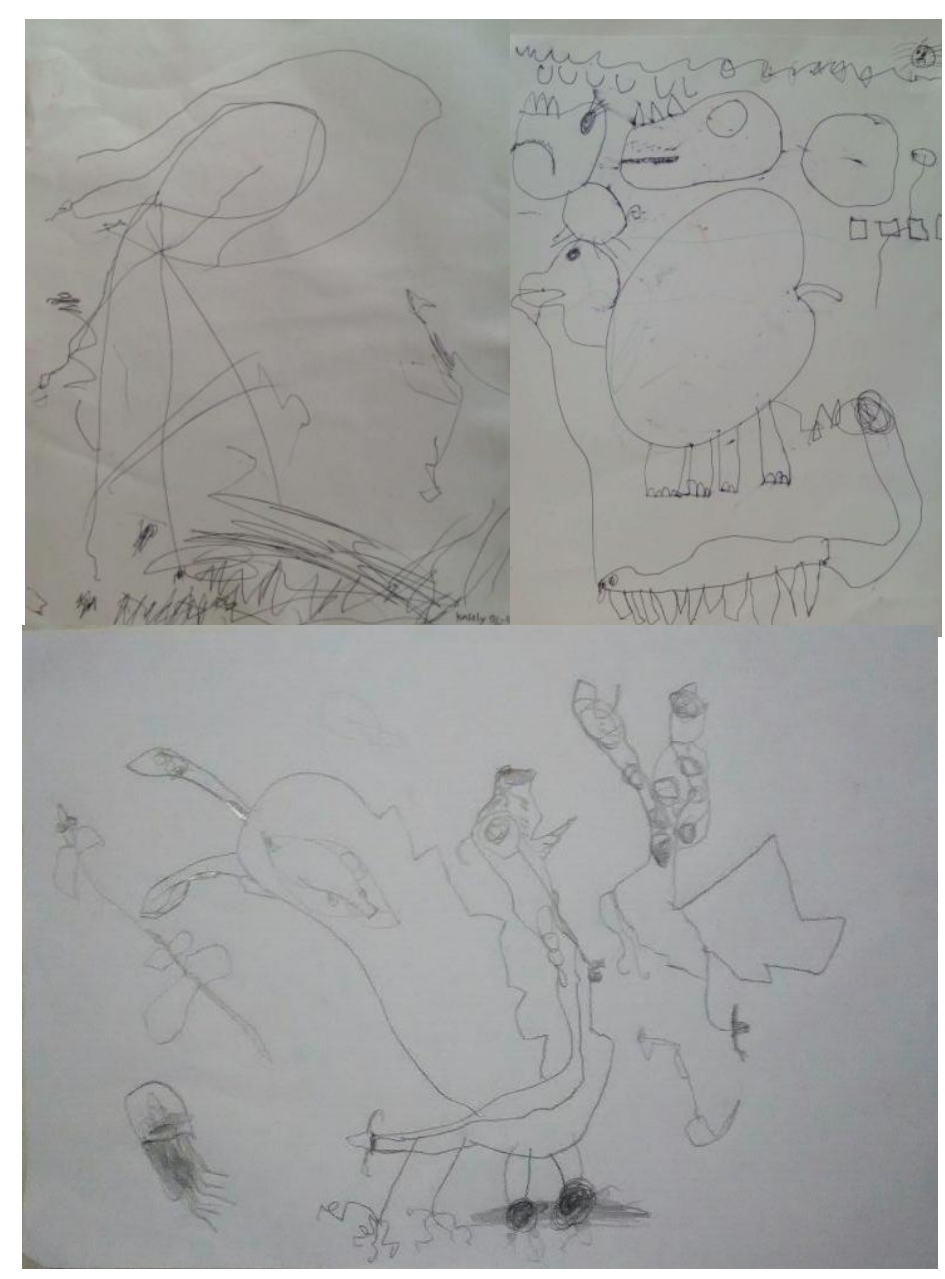

Keterangan:

a) Gambar anak kedua saat memulai menyenangi kegiatan menggambar di usia 2 tahun

b) Gambar anak kedua dalam hubungannya dengan makhluk-makhluk super kuat dan besar seperti Dinosaurus yang digemari anak laki-laki pada umumnya.

c) Gambar anak kedua yang mencoba lebih detail menceritakan tentang T-Rex.

Hadirnya karya anak ketiga berjenis kelamin perempuan semakin melengkapi informasi terkait perkembangan anak yang dapat dipantau melalui gambar. Coretan yang dihasilkan anak ketiga jauh lebih banyak dan lebih berani 
dibanding anak pertama dan anak kedua. Kemudian muncul spot yang yang menjadi objek penekanan menggambar apakah dengan cara diulang-ulang atau digambari berlapis-lapis dan tidak sama rata di semua tempat. Keberanian ini muncul diasosiasikan berasal dari pengamatan saat melihat anak pertama dan kedua menggambar sehingga tanpa ada ketakutan dan keraguan, anak ketiga pun mampu menciptakan garis-garis coretan serupa yang lebih berani.

Selanjutnya gambar-gambar yang dihasilkan anak ketiga yang berusia 2 tahun:

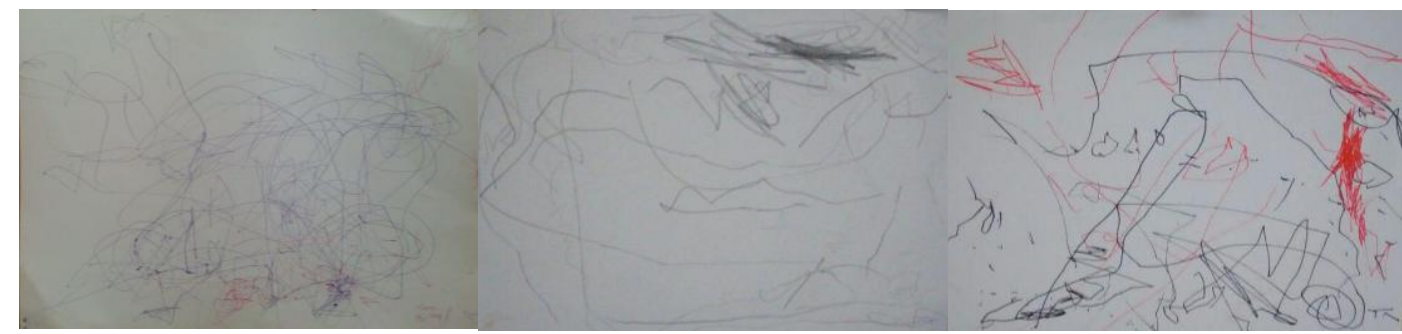

Keterangan:

a) Gambar anak ketiga saat memulai menyenangi kegiatan menggambar di usia 2 tahun mengikuti jejak kakak-kakaknya.

b) Gambar anak ketiga yang diberi penekanan dengan coretan yang lebih banyak pada bagian tertentu menandakan intensitas yang berbeda.

c) Gambar anak ketiga yang telah divariasikan dengan tinta berbeda

Pada aktivitas sosial dan interaksi pun, anak ketiga mampu tampil mendominasi kehadiran saudara-saudaranya yang lebih tua. Menyanyi dengan teks atau kata-kata yang masih belum fasih, menari berputar-putar dan menonton siaran televisi seperti film kartun seolah mengerti jalan ceritanya seperti yang dilakukan anak pertama dan kedua dipelihatkan oleh anak ketiga. Hal ini menandakan bahwa ternyata benar bahwa perkembangan bahasa anak juga ditandai oleh adanya rancangan psikomotorik (Piaget, 1954).

Seringnya anak ketiga terlibat pada aktivitas yang sama sebagaimana yang dilakukan dan dialami oleh anak pertama dan kedua membawa pengaruh besar pada perkembangan anak ketiga. 
Lebihl lanjut, lukisan yang dihasilkan ketiga anak sesuai usianya sekarang dibandingkan, antara yang berusia 6 tahun, 4 tahun, dan anak yang berusia 2 tahun

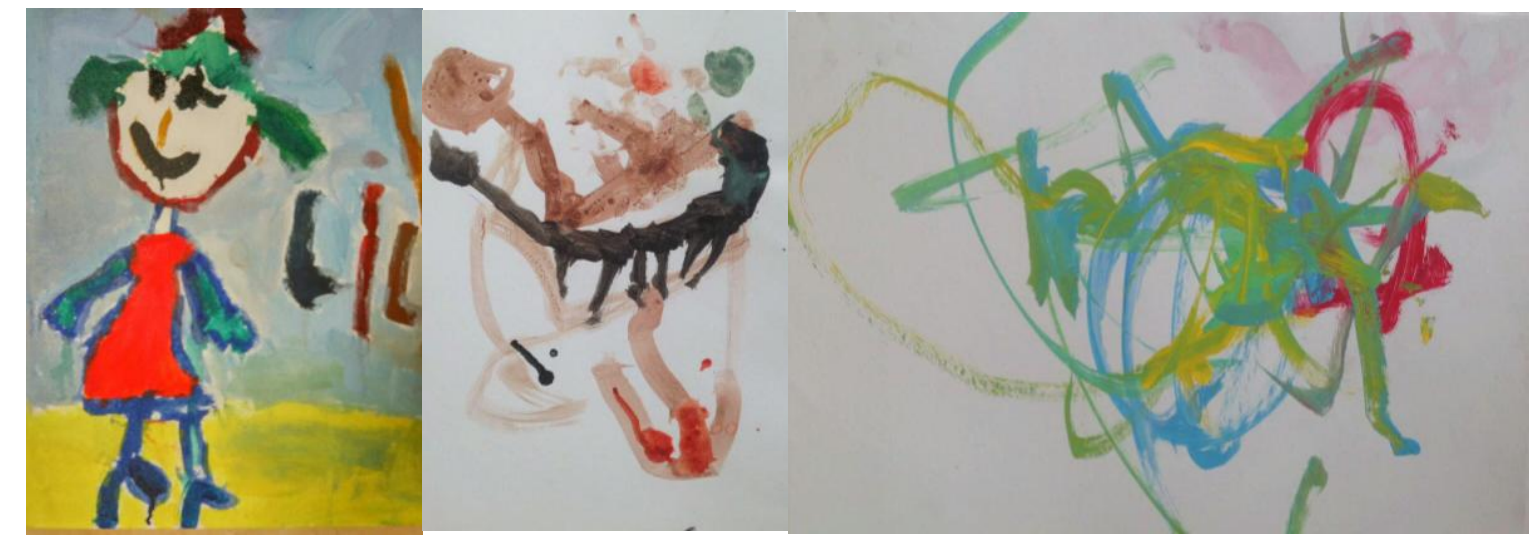

Keterangan:

a) Lukisan anak pertama yang mencoba menceritakan figur anak perempuan yang kemudian diberi namanya sendiri.

b) Lukisan anak kedua yang mencoba menceritakan karakter dinosaurus yang digemarinya

c) Lukisan anak ketiga yang sudah memadu padankan warna-warna berbeda dengan cat air.

\section{PENUTUP}

\section{Kesimpulan}

Dukungan

Meskipun dalam tahapan perkembangan awal, anak pertama dan anak kedua menjadi pemicu terjadinya percepatan perkemangan anak ketiga. Saat orang tua memberikan bentuk pengasuhan langsung atau tidak langsung kepada orang-orang yang dipercayai menjaga anak, anak ketiga memahami dan mencermati lingkungan sosialnya lebih cepat. Instruksi-instruksi yang pada dasarnya ditujukan pada anak pertama dan kedua, tetapi hal yang sama bagi anak ketiga dirasa juga ditujukan pada dirinya. 


\section{Kritik}

Porsi pengarahan pada anak pertama, kedua, dan ketiga seharusnya tidak seragam. Namun kesibukan orang tua bekerja yang membuat hal ini menjadi hal dominan yang mempengaruhi perkembangan anak. Menjadi berpikir dan bertindak lebih maju dibanding anak-anak seusianya adalah baik namun akan lebih bermakna jika hal tersebut tidak malah membuat anak ketiga menjadi berperilaku, beraktivitas sama semua seperti kakak-kakaknya yang lebih tua.

\section{Saran}

Dalam hal percepatan perkembangan anak bungsu yang orang tuanya bekerja perlu disyukuri sebagai suatu berkah. Dapat diambil hikmahnya karena kalau selalu berada di samping orang tua, anak berkemungkinan menjadi anak yang manja. Orang tua diharapkan tetap memberikan perhatian penuh di sela-sela kesibukan dan mengawasi aktivitas anak agar tidak kebablasan. Teknologi informasi yang berkembang pesat dan keseharian orang tua yang tidak dapat dipisahkan dengan smartphone memberi pengaruh juga kepada kemudahan anakanak untuk berhubungan dan bersentuhan dengan perangkat tersebut. Jika orang tua anak baru menyentuh kecanggihan tersebut pada usia di atas 30-an, sekarang anak-anak mereka dalam usia yang lebih belia lagi, seperti si bungsu yang baru berusia 2 tahun. Diperlukan tindakan orang tua untuk memperketat aturan dan batasan hal yang boleh dan tidak untuk anak.

\section{UCAPAN TERIMA KASIH}

Tulisan ini berhasil dirangkum atas dorongan dosen pembimbing, Prof. Dr. Neviyarni S. MS supaya mahasiswa Program Doctoral (S3) UNP mampu memberi kontribusi pada pengembangan psikologi pendidikan dan pembelajaran di sekolah atau perguruan tinggi dengan komentar-komentar dan saran-saran selama perkuliahan berlangsung. 


\section{DAFTAR PUSTAKA}

Glennie, Elizabeth J., Karen J. Charles, and Olivia N. Rice. (2017). Teacher Logs: A Tool for Gainning a Comprehensive Understanding of Classroom Practice. Journal Sciece Educator, Winter 2017 Vol.25, No.2

Hughes, Diana, Woodcock, Jayne, and Funnel Elaine. (2005). Conception of objects across categories: Chilhood patterns resemble those of adults. British Journal of Psychology; Feb 2005, 96.

Mesel, Benjamin De. (2016). Seing Color, Seeing Emotion, Seeing Moral Value. Journal Value Inquiry, 50, 539-555

Rakover, Sam S. (2002). Featural vs. Configuration information in faces: A conceptual and empirical analysis. Journal of Psychology, Feb 2002; 93 